\title{
Analisis Permasalahan Usaha Garam Rakyat di Kecamatan Kwanyar Kabupaten Bangkalan
}

\author{
[Analysis of People's Salt Business Problems \\ in Kwanyar District, Bangkalan Regency] \\ Al Farisi Aminuloh, Lilis Supenti, Kamsiah \\ Jurusan Penyuluhan Perikanan, Sekolah Tinggi Perikanan \\ Jalan Cikaret No. 2, Bogor Selatan, Kota Bogor 16132 \\ Diterima : 15 Januari 2019; Disetujui : 15 Maret 2019
}

\begin{abstract}
Abstrak
Kegiatan penelitian ini bertujuan untuk menganalisis permasalahan mengenai (1) karakteristik dan potensi usaha garam (2) sistem produksi tambak garam (3) sistem usaha tambak garam (4) sistem sosial dan penyuluhan tambak garam. Penelitian dilakukan di Kecamatan Kwanyar Kabupaten Bangkalan, pada bulan November 2018. Teknik pengumpulan data menggunakan kuesioner, wawancara, dan observasi sedangkan teknik analisis data menggunakan analisis deskriptif. Hasil penelitian menunjukkan bahwa: (1) Kecamatan Kwanyar memiliki ketersediaan air laut sebagai bahan baku pembuatan garam sepanjang tahun sehingga berpotensi dalam usaha tambak garam rakyat; (2) di Kecamatan Kwanyar memiliki permasalahan sistem produksi yaitu kegiatan dipengaruhi oleh musim, usaha tambak garam konvensional hanya dilakukan ketika musim kemarau (3) sistem usaha perikanan di Kecamatan Kwanyar masih belum memiliki lembaga permodalan dan pemasaran yang dapat membantu proses pembangunan skala usaha tambak garam; (4) Belum terdapatnya penyuluhan dan sosialisasi inovasi di bidang usaha garam di Kecamatan Kwayar Kabupaten Bangkalan. Kecamatan Kwanyar memiliki potensi kelautan dalam usaha produksi garam dan permasalahan yang harus segera diselesaikan.
\end{abstract}

Kata kunci : sumber daya alam; sumber daya manusia; Pulau Madura

\section{Abstract}

This research activity aims to analyze problems regarding (1) the characteristics and potential of salt business (2) salt pond production systems (3) salt farm business systems (4) social systems and extension of salt ponds. The study was conducted in Kwanyar District, Bangkalan Regency, in November 2018. Data collection techniques used questionnaires, interviews, and observations while data analysis techniques used descriptive analysis. The results showed that: (1) Kwanyar Subdistrict has the availability of seawater as raw material for making salt throughout the year so that it is potentially in the business of community salt ponds; (2) in Kwanyar Subdistrict has a production system problem, namely activities influenced by season, conventional salt pond business is only carried out during the dry season (3) fisheries business system in Kwanyar SubDistrict still does not have capital and marketing institutions that can help the salt-pond business scale development process ; (4) There has not been any extension and information dissemination on innovation in the salt business in Kwayar Sub-District, Bangkalan Regency. Kwanyar Subdistrict has maritime potential in salt production business and problems that must be resolved immediately.

Keywords: Natural resources, human resources, Madura Island

Penulis Korespondensi

Al Farisi Aminullah | alfar.extention94@gmail.com 


\section{PENDAHULUAN}

Sebagai produk yang sangat penting selain sebagai bahan pangan, garam menjadi bahan baku yang sangat penting bagi industri dalam negeri. Keberadaan garam mutlak diperlukan setiap rumah tangga masyarakat, sehingga diperlukan suatu identifikasi terkait produksi garam, salah satu daerah potensial penghasil garam adalah Pulau Madura. Pulau Madura terdapat empat kabupaten yang berpotensi dalam produksi garam yaitu: Kabupaten Bangkalan, Sampang dan Pamengkasan serta Sumenep. Pada tahun 2015 Kabupaten Bangkalan memiliki nilai produksi sebesar 9.500 ton garam, Kabupaten Sampang sebesar 398.983,61 ton dan Kabupaten Pamengkasan sebesar $123.534,65$ ton serta Kabupaten Sumenep 236.117,96 ton. Dari total produksi mencapai 768.136,22, produksi daerah ini mencapai 39,45\% dari produksi nasional garam di Indonesia (Pusdatin KKP 2017).

Kecamatan Kwanyar memiliki 16 Desa/Kelurahan, dengan luas 47,97 km² atau 4797 ha, pada ketinggian 6-24 meter diatas permukaan laut (mdpl). Kecamatan ini memiliki suhu mencapai $32^{\circ} \mathrm{C}$ yang merupakan kawasan pesisir, berbatasan dengan Selat Madura. Sumberdaya alam di Kecamatan Kwanyar di dominasi oleh kegiatan usaha perikanan, baik perikanan tangkap, budidaya, pengolahan dan pemasaram maupun usaha garam. Namun sayang kegiatan usaha garam belum mendapatkan perhatian lebih dibanding kegiatan usaha perikanan lainnya. Perpanjang garis pantai yaitu 17,4 km di Kecamatan Kwanyar hanya $8,2 \mathrm{~km}$, yang dimanfaatkan atau $48,6 \%$ dari panjang pantai yang sudah dimanfaatkan untuk usaha perikanan.

Tabel 1. Pemanfaatan Lahan pada 6 Desa Potensi Perikanan dalam (Ha)

\begin{tabular}{llrcccc}
\hline $\begin{array}{c}\text { Kode } \\
\text { desa }\end{array}$ & $\begin{array}{c}\text { Desa / } \\
\text { Kelurahan }\end{array}$ & $\begin{array}{c}\text { Sawah } \\
\text { (ha) }\end{array}$ & $\begin{array}{c}\text { Bangunan } \\
\text { (ha) }\end{array}$ & $\begin{array}{c}\text { Lahan } \\
\text { Perikanan (ha) }\end{array}$ & $\begin{array}{c}\text { Tegalan } \\
\text { (ha) }\end{array}$ & $\begin{array}{c}\text { Total } \\
\text { (ha) }\end{array}$ \\
\hline 001 & Pesanggrahan & 190,00 & 45,00 & 51,00 & 47,00 & 333,00 \\
\hline 002 & Kwanyar barat & 0,00 & 23,20 & 137,00 & 86,50 & 246,70 \\
\hline 006 & Tebul & 0,00 & 35,50 & 29,80 & 158,70 & 224,00 \\
\hline 007 & Karanganyar & 97,00 & 25,50 & 11,00 & 46,70 & 180,20 \\
\hline 012 & Batah Barat & 70,00 & 22,50 & 4,10 & 21,30 & 117,90 \\
\hline 013 & Batah Timur & 75,00 & 39,00 & 54,00 & 182,00 & 350,00 \\
\hline
\end{tabular}

Sumber : Diskominfo Kabupaten Bangkalan (2017) 
Tabel 2. Curah Hujan dan Hari Hujan

\begin{tabular}{llccc}
\hline No & Bulan & Curah hujan $(\mathbf{m m})$ & Jumlah hari & $\begin{array}{c}\text { Rata-rata curah } \\
\text { hujan }\left(\mathbf{m m} \cdot \text { hari }^{-1}\right)\end{array}$ \\
\hline 1 & Januari & 246 & 14 & 17,57 \\
\hline 2 & Februari & 308 & 14 & 22,00 \\
\hline 3 & Maret & 198 & 9 & 22,00 \\
\hline 4 & April & 235 & 9 & 26,11 \\
\hline 5 & Mei & 176 & 9 & 19,56 \\
\hline 6 & Juni & 39 & 3 & 13,00 \\
\hline 7 & Juli & 185 & 9 & 20,56 \\
\hline 8 & Agustus & 2 & 1 & 2,00 \\
\hline 9 & September & 125 & 8 & 15,63 \\
\hline 10 & Oktober & 256 & 14 & 18,29 \\
\hline 11 & November & 344 & 13 & 26,46 \\
\hline 12 & Desember & 282 & 17 & 16,59 \\
\hline & Jumlah & $\mathbf{2 3 9 6}$ & $\mathbf{1 2 0}$ & $\mathbf{2 1 9 , 7 7}$ \\
\hline & Rata-rata & $\mathbf{1 9 9 , 6 7}$ & $\mathbf{1 0}$ & $\mathbf{1 9 , 9 7}$ \\
\hline
\end{tabular}

Sumber : Diskominfo Kabupaten Bangkalan (2017)

Pemanfaatan lahan yang diidenfifikasi terfokus pada 6 desa potensi perikanan yaitu Desa Pesanggrahan, Desa Kwanyar Barat, Desa Tebul, Desa Karanganyar, Desa Batah Barat dan Desa Batah Timur. Data pemanfaatan lahan dapat dilihat pada Tabel 1.

Kondisi jumlah penduduk di Kecamatan Kwanyar sebanyak 58.413 jiwa dengan jumlah laki-laki sebesar 28.262 jiwa dan jumlah perempuan sebesar 30.151 jiwa, terbagi dalam 14.235 KK. Jumlah rumah tangga perikanan (RTP) mencapai 944 jiwa atau sekitar 1,61\% dari jumlah penduduk, RTP tersebut terbagi atas beberapa sub sektor perikanan yang meliputi perikaanan tangkap, budidaya perikanan, pengolahan dan pemasaran produk perikanan serta usaha garam rakyat.

Kondisi sumberdaya alam dan sumberdaya manusia yang ada di Kecamatan Kwanyar menunjang dalam keberlanjutan usaha perikanan. Usaha perikanan tersebut khususnya dalam sektor usaha garam rakyat. Usaha ini perlu mendapatkan perhatian khusus. Suhu dan iklim serta curah hujan cukup rendah. Berdasarkan hasil pengukuran suhu rata-rata yang terdapat pada desa potensial perikanan di Kecamatan Kwanyar suhu mencapai $32^{\circ} \mathrm{C}-34^{\circ} \mathrm{C}$. Suhu ini termasuk iklim panas, karena 
selain merupakan kawasan pesisir hal ini dikarenakan Kecamatan Kwanyar juga sangat berpotensi dalam usaha garam, curah hujan juga tergolong rendah, berdasarkan informasi rata-rata curah hujan mencapai 199,67 mm.bulan-1. Curah hujan dan hari hujan dapat diamati pada Tabel 2.

Potensi dan keadaan tersebut harus mendapatkan perhatian guna tetap berjalannya kegiatan usaha garam rakyat. Kegiatan penyuluhan yang ada belum mendapatkan perhatian khusus dalam penanganan penyuluhan. Salah satu penyebabnya adalah dikarenakan terbatasnya jumlah tenaga penyuluh di Kecamatan Kwanyar. Perlu adanya kegiatan penelitian yang mampu memberikan hasil identifikasi serta mampu memberikan analisis permasalahan. Melalui analisis permasalahan diharapkan dapat dilakukan upaya atau tindak lanjut hal yang harus dilakukan melalui suatu programa penyuluhan perikanan yang terstruktur dan sesuai dengan kebutuhan usaha tambak garam.

Penyusunan RKPP Kecamatan Kwanyar dan programa penyuluhan perikanan Kecamatan Kwanyar perlu disesuaikan dengan kondisi, potensi, masalah dan karakteristik sasaran penyuluhan yaitu RTP atau kelompok. Penentuan masalah dapat dilakukan melalui Participatory Rural Appraisal (PRA). Participatory Rural Appraisal (PRA) atau Memahami Desa Secara Partisipatif, artinya memberikan sebuah gambaran tentang adanya perkembangan kelompok pendekatan dan metode yang memberikan kesempatan pada masyarakat desa untuk turut ambil bagian dalam menambah dan menganalisis pengetahuan tetang kondisi kehidupannya dalam rangka menyusun perencanaan dan aksi tindakan. Chamber dan Conway (1992) mengemukakan bahwa PRA berasal dari dan banyak memberikan kontribusi kepada penelitian partisipatif radikal, analisis agroekosistem, antropologi terapan, peneitian lapang tentang sistem usaha tani dan memahami desa secara cepat (Rapid Rural Appraisal biasa disebut RRA). Hal mendasar yang membedakan antara PRA dengan RRA adalah dalam RRA, informasi informasi lebih banyak diperoleh dan diambil oleh orang luar (outsider); sedangkan dalam PRA masyarakat desa sendiri lebih memiliki dan memanfaatkan informasi tersebut (Amanah 2003). Adapun usaha garam di Kecamatan Kwanyar dapat dilihat melalui Gambar 1. Penelitian bertujuan untuk menganalisis permasalahan mengenai (1) karakteristik dan potensi usaha garam (2) sistem produksi tambak garam (3) sistem usaha 


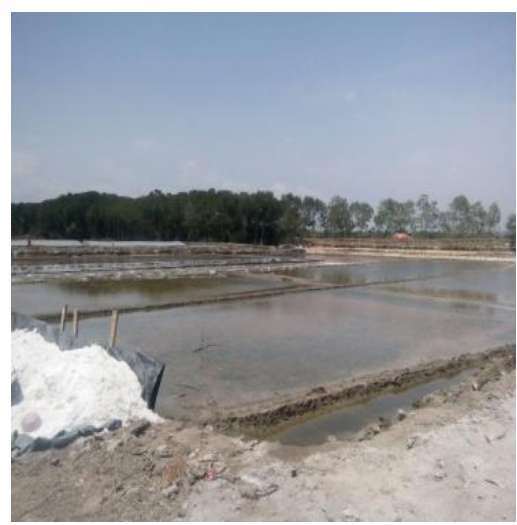

Gambar 1. Kegiatan usaha garam di Kecamatan Kwanyar

tambak garam (4) sistem sosial dan penyuluhan tambak garam.

\section{BAHAN DAN METODE}

Penelitian dilaksanakan pada tanggal 1-30 November 2018 di Kecamatan Kwanyar Kabupaten Bangkalan. Penentuan jumlah sampel yang telah dilakukan untuk menghitung sampel responden dengan menentukan terlebih dahulu jumlah populasi. Berdasarkan informasi yang diperoleh dari penyuluh perikanan dan berdasarkan identifikasi dan pendataaan langsung (enumeration), terdapat 944 Rumah Tangga Perikanan (RTP) dengan keragaan terdapat 816 orang sebagai nelayan, 28 orang sebagai pembudidaya perikanan, 60 orang sebagai pengolah hasil perikanan dan 40 orang sebagai petambak garam.

Penentuan sampel dapat dilakukan dengan menggunakan teknik penentuan sampel menurut Slovin sehingga sampel yang diambil dapat mewakili dari keseluruhan jumlah populasi (Sugiyono 2012). Rumus Slovin yang digunakan dalam penentuan jumlah sampel sebagai berikut :

$$
\begin{gathered}
n=\frac{N}{1+N(e)^{2}} \\
n=\frac{944}{1+944(15 \%)^{2}} \\
n=43 \text { Orang }
\end{gathered}
$$

Keterangan :

$\mathrm{n}=$ Ukuran sampel

$\mathrm{N}=$ Populasi

$\mathrm{e}=$ Persentase ketidakpastian karena kesalahan pengambilan sample yang masih dapat ditolerir atau diinginkan $(5 \%-20 \%)$

Syarat: $\mathrm{N}$ atau Populasi harus lebih dari 100 unit sasaran, apabila kurang dari 100 unit sasaran maka menggunakan sensus / identifikasi keseluruhan.

Berdasarkan jumlah sampel keseluruhan terdapat 43 orang RTP sebagai sampel dengan komposisi 34 RTP nelayan, 2 RTP pembudidaya, 4 RTP pengolah hasil Perikanan dan 3 RTP petambak garam, namun secara 
Tabel 3. Jumlah sampel identifikasi responden di Kecamatan Kwanyar

\begin{tabular}{llccc}
\hline No & Bidang Perikanan & $\begin{array}{c}\text { Populasi } \\
\text { (orang) }\end{array}$ & Persentase (\%) & $\begin{array}{c}\text { Sampel menurut } \\
\text { slovin (orang) }\end{array}$ \\
\hline 1 & Perikanan tangkap & 816 & 86 & 34 \\
\hline 2 & Budidaya perikanan & 28 & 3 & 2 \\
\hline 3 & Pengolahan hasil & 60 & 7 & 4 \\
\hline 4 & Petambak garam & 40 & 4 & 3 \\
\hline & Jumlah & $\mathbf{9 4 4}$ & $\mathbf{1 0 0}$ & $\mathbf{4 3}$ \\
\hline
\end{tabular}

teknis pengambilan data jumlah sampel untuk RTP budidaya, pengolah hasil perikanan dan petambak garam dapat diamati pada Tabel 3.

Analisis permasalahan perikanan dilakukan dengan cara wawancara yaitu responden mengisi kuisioner. Data ini adalah data primer. Data sekunder berupa informasi dari lembaga terkait. Pengolahan data menggunakan metode deskriptif dan statistik yang digunakan untuk menganalisis data yaitu dengan cara mendiskripsikan atau menggambarkan data yang telah terkumpul sebagaimana adanya tanpa bermaksud membuat kesimpulan yang berlaku untuk umum atau generalisasi (Sugiyono 2012).

\section{HASIL DAN PEMBAHASAN}

Hasil

Hasil penelitian menunjukkan terdapat masalah umum dan masalah khusus pada masing masing jenis usaha perikanan di kecamatan Kwanyar yang memiliki sub sektor perikanan yang heterogen. Identifikasi permasalahan pada kegiatan produksi perikanan baik perikanan tangkap, perikanan budidaya maupun pengolahan hasil perikanan serta produksi tambak garam di Kecamatan Kwanyar selanjutnya akan di tampilkan dalam bentuk Tabel 4, berupa permasalahan umum dan permasalahan khusus pada masing-masing bidang produksi perikanan.

Dalam penyelesaian permasalahan yang beragam diperlukan adanya suatu tindak lanjut yang mengarahkan, agar suatu kegiatan penyuluhan dapat segera terlaksana sehingga diperlukan Uji GMP (Gawat, Mendesak, dan Penyebaran) yang nantinya dilaksanakan sesuai proioritas. Adapun Uji GMP diamati pada tabel uji prioritas GMP, Adapun Uji GMP diamati pada Tabel 5. 
Tabel 4. Masalahan Umum dan Masalahan Khusus Produksi Perikanan.

\begin{tabular}{|c|c|c|}
\hline No & Masalah Umum & Masalah Khusus \\
\hline \multirow[t]{5}{*}{1} & Penangkapan Ikan & \\
\hline & $\begin{array}{l}\text { Kegiatan Penangkapan belum } \\
\text { optimal karena keterbatasan }\end{array}$ & $\begin{array}{l}\text { Terlalu Padatnya Pemilik kapal dan area } \\
\text { tangkap yang terbatas }\end{array}$ \\
\hline & $\begin{array}{l}\text { pengetahuan, keterampilan dan } \\
\text { sikap }\end{array}$ & $\begin{array}{l}\text { Kurangnya keterampilan dalam penanganan } \\
\text { paska tangkap }\end{array}$ \\
\hline & & $\begin{array}{l}\text { Banyaknya sampah yang ikut tertangkap } \\
\text { pada jaring }\end{array}$ \\
\hline & & $\begin{array}{l}\text { Tidak terdapat TPI sehingga hasil tangkapan } \\
\text { tidak tercatat. }\end{array}$ \\
\hline \multirow[t]{4}{*}{2} & Budidaya Perikanan & \\
\hline & $\begin{array}{l}\text { Kegiatan Budidaya permasalahan } \\
\text { pada kegiatan kontrol lingkungan }\end{array}$ & $\begin{array}{l}\text { Belum Tersedianya Laboratorium untuk } \\
\text { mengontrol hama dan penyakit }\end{array}$ \\
\hline & & $\begin{array}{l}\text { Sistem pembuangan limbah air langsung } \\
\text { dialirkan ke laut }\end{array}$ \\
\hline & & $\begin{array}{l}\text { Kegiatan sangat bergantung pada Aliran } \\
\text { listrik untuk kincir dan pompa }\end{array}$ \\
\hline \multirow[t]{4}{*}{3} & Pengolahan Hasil Perikanan & \\
\hline & $\begin{array}{l}\text { Permasalahan pada produksi } \\
\text { pengolahan yang masih tradisional }\end{array}$ & $\begin{array}{l}\text { Pengolah belum terdata secara sensus } \\
\text { maupun enumerasi }\end{array}$ \\
\hline & & $\begin{array}{l}\text { Kegiatan pengolahan terbatas pada ikan asin, } \\
\text { terasi dan kerupuk }\end{array}$ \\
\hline & & $\begin{array}{l}\text { Banyak UPI tapi belum terdaftar dan } \\
\text { berkelompok (swadaya) }\end{array}$ \\
\hline \multirow[t]{5}{*}{4} & Kegiatan Pembuatan Garam & \\
\hline & $\begin{array}{l}\text { Kegiatan teknis sangat terkendala } \\
\text { terhadap kualitas air laut dan musim }\end{array}$ & $\begin{array}{l}\text { Kegiatan Pembuatan Garam hanya pada } \\
\text { bulan Juni-Oktober }\end{array}$ \\
\hline & & $\begin{array}{l}\text { Kualitas Air laut sisa tambak masuk ke aliran } \\
\text { pembuatan garam }\end{array}$ \\
\hline & & $\begin{array}{lll}\text { Pembuatan } & \text { garam } & \text { terkendala } \\
\text { stok/ketersediaan air tua } & \end{array}$ \\
\hline & & $\begin{array}{l}\text { Kualitas Garam masih sebagai Garam rakyat, } \\
\text { yang dibutuhkan garam industri. }\end{array}$ \\
\hline
\end{tabular}

Analisis data yang digunakan dalam permasalahan yang terdapat di dalam praktek keahlian menggunakan diagram tulang ikan (fishbone). Diagram fishbone merupakan diagram yang menggambarkan cause (penyebab) dalam suatu kategori menjadi effect (akibat) serta kepala ikan (fish head) sebagai tujuan yang ingin dicapai. Gambaran permasalahan tersebut merupakan bagian dari Rencana Kerja Penyuluh Perikanan (RKPP) di Kecamatan Kwanyar Kabupaten Bangkalan. Untuk lebih jelasnya dapat diamati pada Gambar 4. 
Tabel 5. Uji Prioritas (GMP)

\begin{tabular}{|c|c|c|c|c|c|c|}
\hline \multirow{2}{*}{ No } & \multirow{2}{*}{ Akar Masalah } & \multicolumn{3}{|c|}{ Nilai Skor (1-3) } & \multirow{2}{*}{ Jmlh } & \multirow{2}{*}{$\begin{array}{l}\text { Prioritas } \\
\text { Kegiatan }\end{array}$} \\
\hline & & $\mathbf{G}$ & M & $\mathbf{P}$ & & \\
\hline 1. & $\begin{array}{l}\text { Kegiatan Pembuatan Garam } \\
\text { teknologi intensif, yang dapat } \\
\text { dioperasionalkan saat musim } \\
\text { penghujan dan tandon penampung } \\
\text { air tua. }\end{array}$ & 3 & 2 & 2 & 7 & 1 \\
\hline 2. & $\begin{array}{l}\text { Kegiatan sensus pengolahan dan } \\
\text { demcar Pembuatan olahan modern } \\
\text { serta SIUP pada UPI }\end{array}$ & 2 & 2 & 1 & 5 & 2 \\
\hline 3. & $\begin{array}{l}\text { Penanganan tangkap, BST, } \\
\text { peningkatan keterampilan dalam } \\
\text { pasca tangkap pada kegiatan } \\
\text { perikanan tangkap. }\end{array}$ & 2 & 1 & 2 & 5 & 3 \\
\hline 4. & $\begin{array}{l}\text { Kegiatan budidaya ikan yang } \\
\text { menerapkan tecnopark, budidaya } \\
\text { dengan ekosisitem terpadu dan } \\
\text { ramah lingkungan }\end{array}$ & 1 & 1 & 2 & 4 & 4 \\
\hline
\end{tabular}

1. Skor ditentukan berdasarkan kesepakatan masyarakat pelaku utama perikanan dengan tim, misal 1-3

2. Gawat : merupakan hasil penilaian besar/kecilnya akibat/kerugian bagi pelaku utama yang ditimbulkan dari masalah tersebut ( 1 = tidak gawat, 2 = cukup gawat, 3 = sangat gawat)

3. Mendesak : bila masalah tersebut tidak segera diselesaikan maka akan berdampak pada seluruh kegiatan ( 1 = tidak gawat, 2 = cukup gawat, 3 = sangat gawat)

4. Penyebaran : merata atau hanya parsial saja masalah tersebut muncul, semakin merata penyebarannya semakin tinggi (presentasi jumlah peserta yang hadir) $(1=$ tidak gawat, 2 = cukup gawat, 3 = sangat gawat)

Penyebab dasar yang berbeda disusun berdasarkan kategori dan membentuk suatu pola hubungan cause and effect (hubungan sebab - akibat). Perbedaan ini yang menjadi ketidaktercapainya suatu tujuan kegiatan produksi dan atau usaha perikanan yaitu terciptanya usaha perikanan yang mandiri di Kecamatan Kwanyar Kabupaten Bangkalan khususnya penanganan pada permasalahan usaha tambak garam. Dalam uji GMP diperlukan suatu tindakan langsung melalui aksi penyuluhan.

\section{Pembahasan}

Analisis permasalahan pada kegiatan usaha perikanan di Kecamatan Kwanyar Kabupaten Bangkalan khususnya pada usaha produksi pembuatan garam dipengaruhi oleh masalah umum. Masalah tersebut adalah terkendala pada aspek teknis berupa penuaan air laut dan kegiatan 


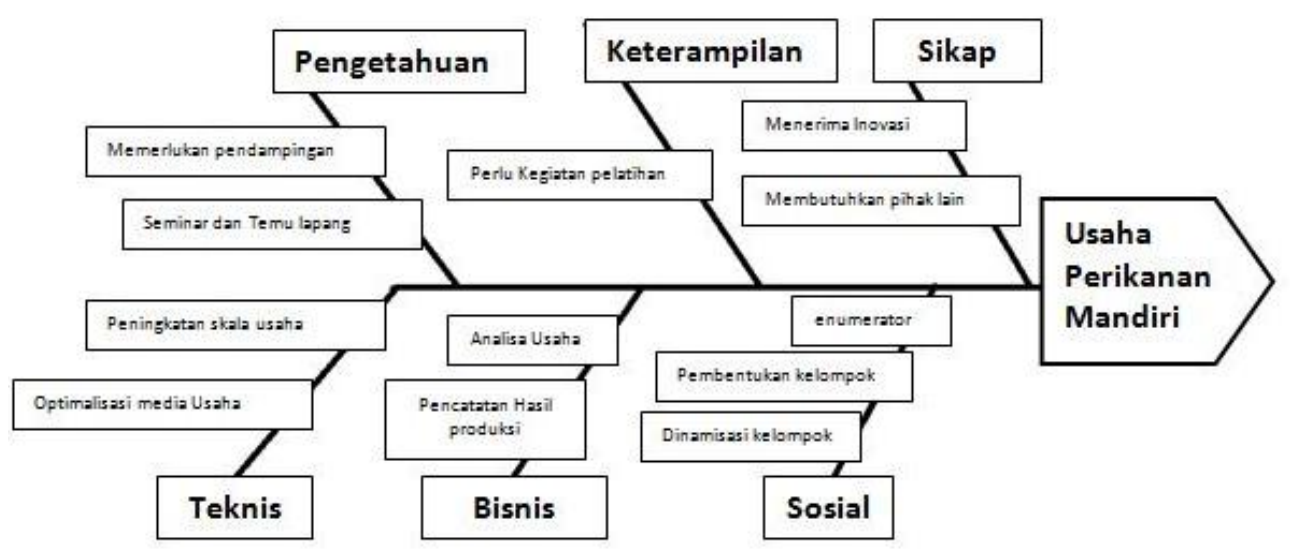

Gambar 4. Diagram Fishbone

Keterangan :

1. Analisis ini dimulai dengan masalah yang harus diselidiki berupa category, berdasarkan permasalahan yang akan dibahas lebih lanjut pada pembahasan selanjutnya category meliputi Pengetahuan, keterampilan dan sikap pelaku utama dan atau pelaku usaha perikanan serta aspek teknis, bisnis dan sosial pelaku utama dan atau pelaku usaha perikanan.

2. Secara spesifik permasalahan yang muncul dalam kegiatan produksi maupun kegiatan usaha perikanan ditulis pada tulang kecil pada masing masing tulang punggung (category). Faktor-faktor inilah yang menjadi kemungkinan penyebab dasar tidak tercapainya suatu tujuan kegiatan produksi maupun kegiatan usaha perikanan di Kecamatan Kwanyar khususnya usaha tambak garam.

3. Panah atau kepala ikan (fish head), akan mengarah ke pertanyaan di bawah pertimbangan, yang merupakan product maupun tujuan dari kegiatan produksi maupun usaha perikanan khususnya garam yaitu usaha perikanan yang mandiri.

tambak garam. Hal ini sangat bergantung terhadap musim sedangkan beberapa masalah khusus diantaranya: Kegiatan lahan garam di Kecamatan Kwanyar Kabupaten Bangkalan dipengaruhi oleh tersedianya panas matahari atau musim kemarau, yang hanya berlangsung selama 5 bulan, yaitu dari bulan Juni bulan Oktober. Faktor cuaca merupakan faktor yang sangat penting dalam usaha pembuatan garam. Faktor inilah yang menjadi faktor utama dalam keberlangsungan (sustainable). Hal tersebut merupakan masalah yang sama terhadap usaha petambak garam baik di daerah Bangkalan maupun daerah lain. Herho, Firdaus, and Siregar (2017) menjelaskan tentang pengaruh aspek meteorologi terhadap produksi garam di Desa Losarang Kabupaten Indramayu, kegiatan usaha garam sangat dipengaruhi oleh curah hujan, evaporasi, perawanan dan angin permukaan. Akibat dari musim ini mengakibatkan usaha 
garam konvensional berlangsung selama musim kemarau saja, dengan jumlah produktivitas luas mencapai 72 ton.ha-1 sedangkan di Kecamatan Kwanyar mencapai 76 ton. ha ${ }^{-1}$ dalam satu siklus usaha garam.

Pengaruh kegiatan cuaca juga berpengaruh terhadap kegiatan usaha garam. Sifat garam yaitu higroskropis artinya mudah terlarut dalam air, dan mengalami perubahan wujud saat bercampur dengan konsentrasi garam yang berbeda (Purbani 2015). Kurniawan dan Azizi (2012) menjelaskan kegiatan garam akan mengalami kerusakan apabila tercampur dengan air hujan. Tambak garam akan berhenti beroperasi pada waktu musim penghujan tersebut. Akibatnya kegiatan lahan konvensional tidak berjalan di musim penghujan. Berdasarkan penelitian ini yaitu identifikasi, pelaku usaha garam pada musim kemarau menjalankan usaha garam. Sedangkan pada musim penghujan tidak melakukan usaha dan pengangkutan karena kualitas garam akan menurun ketika perubahan musim. Diperlukan suatu langkah kegiatan penyuluhan guna menerapkan inovasi yang mampu menghasilkan operasional produksi garam di musim penghujan. Diharapkan usaha garam sebagai mata pencaharian utama berlangsung sepanjang tahun. Hal tersebut mulai diterapkan di daerah lain seperti penerapan prisma garam di Kabupaten Tegal, Jawa Tengah yang mampu menerapkan teknologi prisma garam.

Faktor masalah khusus yaitu ketersediaan air tua sebagai bahan baku utama usaha garam dan masuknya air laut sisa kegiatan perikanan menuju air penampungan lahan garam. Ketersediaan air tua menjadi sangat penting dan menjadi masalah dalam pembuatan garam secara konvensional. Kualitas air garam seperti salinitas yang diperlukan pada saat pembuatan garam adalah mencapai 29-32 ppt. Pada saat musim kemarau salinitas mencapai 34 ppt sedangkan pada musim penghujan salinitas di Selat Madura mencapai 20 ppt. Dalam pembuatan garam untuk mencapai air tua harus dapat mencapai nilai Be atau Baume, Nilai ini diukur menggunakan baume meter. Permasalahan ketersediaan nilai $\mathrm{Be}$ pada lahan konvensional usaha tambak garam rakyat adalah ketika awal musim kemarau petambak garam belum memiliki wadah atau tandon yang mampu menyimpan air yang memiliki nilai Be diatas $5^{\circ} \mathrm{Be} \mathrm{Hal}$ ini merupakan permasalahan yang terjadi di kawasan pesisir Selat Madura.

Selain faktor ketersedian air juga terdapat permasalahan. Masuknya sisa usaha budidaya udang vanamei kedalam lahan operasional tambak garam dan sisa air yang dihasilkan oleh usaha 
budidaya udang vannamei memiliki kandungan seperti magnesium (Mg) yang tidak seharusnya masuk kedalam lahan pembuatan garam. Hal ini menyebabkan dapat mempengaruhi kualitas garam yang dihasilkan. Selain itu berpengaruh pula secara organoleptik garam yang dihasilkan terlihat kusam. Berdasarkan kegiatan identifikasi diperlukan suatu penanganan guna menjaga agar bahan baku (air laut) yang berasal dari Selat Madura tidak terkontaminasi oleh polutan maupun sisa usaha budidaya udang vanamei maupun komoditas sekitar. Hartoko, Soedarsono, dan Indrawati (2013) menjelaskan ekosistem mangrove dapat menyaring berbagai komponen abiotik seperti Magnesium, Nitrat, Nitrit, Amonia dan zat lain yang dapat menjadi penahan gelombang untuk mencegah Abrasi. Dalam usaha garam konvensional diperlukan filter yang memiliki fungsi sepeti ekosistem manrove agar garam memiliki hasil yang baik dari segi kualitasnya.

Faktor masalah usaha perikanan bidang garam terutama pada aspek bisnis dan penyuluhan serta sosial kegiatan usaha perikanan khususnya pada kegiatan penyuluhan bidang garam yang belum mendapatkan perhatian. Berdasarkan kondisi di Kecamatan Kwanyar terdapat 1 penyuluh perikanan PNS dan 1 penyuluh perikanan bantu pada kondisi di lapangan, penyuluh bantu tersebut menangani 3 kecamatan sekaligus. Undang-Undang Nomor 19 tahun 2013 tentang Pemberdayaan dan Perlindungan Petani menjelaskan jumlah penyuluh yang menangani satu desa adalah satu orang penyuluh. Kecamatan Kwanyar terdiri atas 16 Desa, sehingga permasalahan adalah tenaga penyuluh di Kecamatan Kwanyar masih kurang.

Penyuluhan di Kecamatan Kwanyar kususnya di bidang garam masih belum mendapat perhatian khusus, penyuluh belum memiliki kopetensi keahlian di bidang usaha sub sektor pembuatan garam rakyat. Hal ini menyebabkan belum dapat memberikan materi penyuluhan yang tepat guna terhadap pelaku usaha tambak garam, sehingga penyuluhan di bidang garam belum dapat terstruktur. Penyuluhan belum tersusun dan memiliki konsep sesuai dengan programa penyuluhan perikanan dan Rencana Kerja Penyuluhan Perikanan (RKPP) Kecamatan Kwanyar Kabupaten Bangkalan.

Faktor terakhir yang terjadi pada pelaku usaha garam adalah pengelolaan keuangan yang belum optimal. Pengelolaan keuangan yang belum optimal dapat disebabkan karena pelaku usaha garam belum melakukan analisis kelayakan usaha. Beberapa komponen analisis usaha seperti biaya tenaga kerja 
belum dihitung dalam analisis usaha sehingga diperlukan suatu kegiatan pendampingan agar pelaku usaha garam mampu melakukan manajemen tataniaga usaha garam rakyat. Analisis kelayakan usaha perlu dilakukan agar dapat melakukan usaha secara terstruktur dan terarah (Rahardi 2013). Menurut Heriansyah dan Fathuddin (2014) tentang analisis tata niaga garam untuk pengembangan usaha garam rakyat di Kabupaten Pangkep, manajemen usaha melalui analisis usaha garam mampu meningkatkan kualitas dari pelaku usaha garam agar mampu memaksimalkan produksi secara terstruktur dan memiliki kapasitas yang lebih baik.

\section{SIMPULAN DAN SARAN}

Berdasarkan pembahasan hasil penelitian yang telah dilaksanakan di Kecamatan Kwanyar Kabupaten Bangkalan, dapat disimpulkan sebagai berikut :

1. Karakteristik dan potensi wilayah kelautan dan perikanan di Kecamatan Kwanyar Kabupaten Bangkalan pada 6 desa potensi perikanan yaitu Desa Pesanggrahan, Desa Kwanyar Barat, Desa Tebul, Desa Karanganyar, Desa Batah Barat dan Desa Batah Timur memiliki wiliyah pesisir yang berbatasan dengan selat madura.

2. Sistem produksi perikanan di Kecamatan Kwanyar Kabupaten Bangkalan memiliki sub sistem produksi yang heterogen meliputi penangkapan, budidaya perikanan, pengolahan dan pemasaran hasil perikanan serta usaha tambak garam.

3. Prioritas permasalahan usaha garam adalah produksi usaha tambak garam yang hanya beroperasional di musim kemarau, sehingga kegiatan usaha tidak berlangsung sepanjang tahun, sehingga diperlukan suatu teknologi yang mampu menjalankan usaha dapat berjalan sepanjang tahun.

4. Sistem penyuluhan perikanan di Kecamatan Kwanyar memiliki 1 penyuluh perikanan PNS 1 penyuluh perikanan bantu yang memiliki tugas di 3 kecamatan dan yang tidak sejalan dengan UU No 19 tahun 2013 dan masih banyak pelaku petambak garam yang melalkukan kegiatan usaha melalui manajemen usaha yang sesuai dengan kapasitas pelaku usaha perikanan.

\section{DAFTAR PUSTAKA}

Amanah, Siti. 2003. "Metode PRA dan RRA." in Prossiding Pelatihan untuk pelatih Pengelolaan Wilayah 
Pesisir Terpadu. Bogor (ID): Institut Pertanian Bogor.

Chamber, Robert dan Gordon R. Conway. 1992. "Sustainable Livelihood: Practical Concept For The 21 st Century."

Diskominfo Kabupaten Bangkalan. 2017.

"Statistik Daerah Bangkalan 2017." Hartoko, Agus, Prijadi Soedarsono, dan Ayuningtyas Indrawati. 2013. "Analisis Klorofil- $\alpha$, Nitrat dan Fosfat pada Vegetasi Mangrove Berdasarkan Data Lapangan dan Data Satelit Geoeye di Pulau Parang, Kepulauan Karimunjawa." Journal of Management of Aquatic Resources 2(2):28-37.

Herho, Sandy H. S., Gisma A. Firdaus, dan Plato M. Siregar. 2017. "Pengaruh Aspek Meteorologi Terhadap Produksi Garam Air Payau Di Desa Losarang, Kabupaten Indramayu." in SEMIRATA MIPAnet. Manado: Universitas Sam Ratulangi.

Heriansyah dan Fathuddin. 2014.

"Analisis Tataniaga Garam dalam Pengembangan Usaha Garam Rakyat di Kabupaten Pangkep." Jurnal Balik Diwa 5(2):1-9.

Kurniawan, Tikkyrino dan Achmad Azizi. 2012. "Dampak Perubahan Iklim Terhadap Petani Tambak Garam di Kabupaten Sampang dan
Sumenep." Jurnal Masyarakat \& Budaya, 14(3):499-518.

Purbani, Dini. 2015. "Proses Pembentukan Kristalisasi Garam, Pusat Riset Wilayah Laut dan Sumberdaya Nonhayati."

Pusdatin KKP. 2017. "Kelautan dan Perikanan Dalam Angka Tahun 2012-2016: Produksi Garam Rakyat." Diambil (http://statistik.kkp.go.id/sidatik$\operatorname{dev} / 2 . p h p ? x=4)$.

Rahardi, F. 2013. Agribisnis Perikanan (edisi revisi). Jakarta (ID): Penebar Swadaya.

Sugiyono. 2012. Metode Penelitian Kuantitatif, Kualitatif dan $R \& D$. Bandung (ID): Alfabeta. 
